\title{
Black Cumin Seed Oilas Hepatoprotector in Decreasing SGPT and SGOT Activity and Increasing p53 Gene Expression in Sprague Dawley Rats Induced by Alloxan
}

\author{
Akrom $^{1,2}$, Endang Darmawan ${ }^{1}$, Liesma Yuhelvia ${ }^{1}$ \\ ${ }^{1}$ Faculty of Pharmacy, Universitas Ahmad Dahlan, Yogyakarta, Indonesia \\ ${ }^{2}$ Drug Information and Crisis Center, Universitas Ahmad Dahlan, Yogyakarta, Indonesia
}

\section{Article Info}

Article history:

Received Jun 27, 2015

Revised Aug 20, 2015

Accepted Aug 29, 2015

Keyword:

Alloxan

Black cumin seed oil

Hepatoprotector

Immunohistochemistry

Nigella sativa $L$

Oxidative stress

\begin{abstract}
The objective of this research was to determine the effect of BCSO on SGPT/SGOT levels and p53 expression in rats induced by alloxan. This study applied a post test only control group design. A total of $42 \mathrm{SD}$ rats were divided into 6 groups. Group I was normal rats. Group II (negative control) was given alloxan. Group III and IV (treatment groups) were given BCSO with equivalent doses of $6.8 \mathrm{mg} / \mathrm{kg}$ and $68 \mathrm{mg} / \mathrm{kg}$ thymoquinone, respectively (BCSO 6.8 and BCSO68 groups). Group V (positive control) was given vitamin C. Group VI (control media) were given DMSO. BCSO and Vitamin $\mathrm{C}$ are given for 1 week. Alloxan was given on $7^{\text {th }}$ day, i.p. On the $8^{\text {th }}$ day did blood sampling for measurement of SGPT and SGOT levels. Liver retrieval was performed on the $9^{\text {th }}$ day continued immunohistochemistry staining. The average levels of SGPT/SGOT were then analyzed with ANOVA test. p53 expression was analyzed by Kolmogorov Semirnov and Levene then followed by Kruskal Wallis and Mann-Whitney. Statistical tests performed on $95 \%$ confidence level. The results showed that the induction of alloxan increased levels of SGPT/SGOT. BCSO68 reduced SGPT /SGOT levels in alloxan-induced rats $(\mathrm{p}<0.05)$. Both BCSO 6.8 and BCSO68 increased the expression of p53 in liver tissue of alloxan - induced rats. Average percentage of p53 expression in group I to group VI were $11.12 \pm 0.37 ; 19.24 \pm 4.47 ; 30.31 \pm 1.59 ; 40.43 \pm 1.74 ; 29.67$ $\pm 0.47 ; 12.02 \pm 1.01$, respectively. The result of statistical analysis showed the value of $\mathrm{p}<0.05$ in all groups except in group III. It can be concluded that BCSO may have hepatoprotective effect and increase the expression of p53 in the liver of alloxan-induced rats.
\end{abstract}

Copyright () 2015 Institute of Advanced Engineering and Science. All rights reserved.

\section{Corresponding Author:}

Akrom,

Department of Pharmacology and Clinical Pharmacist,

Faculty of Pharmacy, Universitas Ahmad Dahlan,

Drug Information and Crisis Center, Universitas Ahmad Dahlan,

Phone: +62813 28123818 .

Email :akrom@pharm.uad.ac.id

\section{INTRODUCTION}

Oxidative stress can affect various organs. Instead of pancreas, one of organ which is vulnerable to damage due to oxidative stress is liver. Liver is the largest organ in the body which has a variety of functions to sustain the survival of most organs in the body. Hepatic dysfunction demonstrated by the increased activity of the SGPT and SGOT enzyme [1],[2].

The prevention of degenerative diseases due to oxidative stress can be done by consuming antioxidants [3],[4]. Black cumin seed oil (BCSO) has the main compound of thymoquinone allegedly having hepatoprotective activity through antioxidative mechanism [5],[6]. Previous research reported 
thymoquinone has an antioxidant, anti-infective, and antihistamine effects [7]-[9]. But the mechanism of BCSO protects the liver function and p53 expression in rat was unknown. This study was aimed to determine the effect of BCSO on levels of SGOT/SGPT and p53 expression in liver rats induced by alloxan.

\section{RESEARCH METHOD}

\subsection{Materials}

Black cumin seeds were obtained from the distributor of herbal ingredients in Semarang. The authenticity of black cumin seeds carried out at the Laboratory of Pharmaceutical Biology, Faculty of Pharmacy, Gadjah Mada University, Yogyakarta. Other materials are white male rats (Rattus norvegicus) Sprague Dawley strain obtained from BPOM Jakarta, distilled water, alloxan, dehydration solution (alcohol $70 \%, 90 \%, 95 \%$, and absolute), clearing solution (xylol), PBS, normal serum, H2O2, methanol, anti-p53 monoclonal antibody, paraffin, $0.9 \% \mathrm{NaCl}$ physiological, xylene, peroxidase blocking solution, chromogen DAB (Diaminobenzinidine) and hematoxylin eosin.

\subsection{Methods}

\subsubsection{Preparation of BCSO}

BCSO was obtained by pressing black cumin seeds. Black cumin seeds $400 \mathrm{~g}$ pressed with engine power of 600 tons. The oil was collected in a petri dish seteril to be stored at room temperature.

\subsubsection{The hepatoprotective activity test of BCSO induced by alloxan}

Forty two rats were divided into six groups, each consisting of 7 animals. Group I (normal), Group II (ill), Group III, IV were treated by BCSO at dose $6.8 \mathrm{mg} / \mathrm{kg}$ and $68 \mathrm{mg} / \mathrm{kg} \mathrm{BW}$. Group V as the positive control group were given vitamine C. Group VI was a control solvent given DMSO. BCSO and Vitamin C were given during one week, then alloxan was given on day 7 .

\subsubsection{Measurement of SGPT and SGPT level}

Blood samples was inserted into ependroff containing heparin. The blood centrifuged at a speed of $4000 \mathrm{rpm}$. Once centrifuged, the samples were separated by using pipet. SGPT/SGOT levels of samples was determined using $200 \mathrm{~mL}$ sample which was added in $1000 \mu$ lmonoreagen. Each incubated at a temperature of $250 \mathrm{C}$ for 60 seconds and then read at a wavelength of $344 \mathrm{~nm}$ (A1). Wait 60 seconds and then re-read the absorbance (A2), wait 60 seconds, and read again (A3). Absorbance used to measure levels of SGPT and SGOT using the equation:

Levels of SGOT or SGPT $(\mathrm{U} / \mathrm{I})=\Delta \mathrm{A} / \min \times \mathrm{F}$

Formula:

$\Delta \mathrm{A} / \min =((\mathrm{A} 1-\mathrm{A} 2)+(\mathrm{A} 2-\mathrm{A} 3)) / 2$

$\mathrm{F}=$ Factor $(971)$

\subsection{4. p53 expression examination}

Liver retrieval is performed on 9th day by means of cervical dislocasio. Liver was cut using a microtome. In the dehydration process of tissue sections was added to a solution of the alcohol concentration of multi-storey. The tissue was then put in a solution of pure xylol alcohol during $2 \times 2$ hour. The next process is the impregnation. This process is included in the liquid paraffin tissue for $2 \times 2$ hour. The last step is embedding. In this process the tissue embedded in paraffin solid having a melting point of 560C-580C until the paraffin solidifies [10]. The hepatic sample was finished preparations made Immunohistochemistry staining. p53 expression (brown) was observed in cells using a light microscope with a magnification of 40 times.

\subsubsection{Data Analysis}

Percentage of p53 expression was calculated by (number of cells that expressed / total cell number) x 100\%. Analysis applied the Kolmogorov-Smirnov and Levene statistical tests followed by Kruskal Wallis and Mann-Whitney test on 95\% confidence level. 


\section{RESULTS AND ANALYSIS}

\subsection{Activity SGOT}

The result of SGOT are presented in Table 1. The results showed that administration at equivalent doses BCSO 6.8 and $68 \mathrm{mg} / \mathrm{kg}$ thymoquinone for 7 days did not affect the activity of SGOT. SGOT before induced by alloxan in rats given BCSO and vitamin $\mathrm{C}$ are not different from the normal group. The treatment given to the test animals did not affect the levels of SGOT and does not change the normal conditions. SGOT levels are normal in this study is different from that expressed by Giknis and Clifford (2008) [11] in which the average level of SGOT normal SD rats was $23.35 \pm 1.11 \mathrm{U} / 1$. Solvent DMSO group had higher levels compared to the normal group $(p<0.05)$. Himawan (2008) [12] states that the factors affecting the levels of SGOT, among others, the psychological condition of rats, liver disease, or immune from each of the test animals. Moreover, according to Walter (2008) [13] that DMSO can cause side effects that damage the liver and kidneys that can cause increased SGOT.

Table 1. The SGOT level of rats pre- and post- induced by alloxan with treatment of BCSO or vitamin C

\begin{tabular}{ccc}
\hline Groups & \multicolumn{2}{c}{ SGOT level } \\
\cline { 2 - 3 } & Pre(mean \pm SD) U/I & Post (mean \pm SD) U/I \\
\hline Normal & $23.35 \pm 1.107$ & $23.71 \pm 0.542^{\mathrm{a}}$ \\
Negative control (alloxan) & $23.35 \pm 1.107$ & $33.62 \pm 0.469^{*}$ \\
BCSO 6.8 & $23.44 \pm 0.464$ & $34.88 \pm 0.600^{*} \&^{* *}$ \\
BCSO 68 & $23.58 \pm 0.619$ & $30.24 \pm 0.539^{* \mathrm{a}}$ \\
Vitamin C & $22.42 \pm 0.720$ & $27.86 \pm 0.552^{* \mathrm{a}}$ \\
DMSO & $25.38 \pm 0.461^{*}$ & \\
\hline
\end{tabular}

Ext: $*=p<0.05$ (significant difference to normal group); $* *=p>0.05$ (not significant difference to alloxan group); $\mathrm{a}=\mathrm{p}<0.05$ (significant difference to alloxan group)

Alloxan induction on day 7 shown to increase the activity of SGOT. Negative group, have a higher activity than normal SGOT $(\mathrm{p}<0.05)$, indicating that the administration of alloxan affect liver function and increasing the activity of SGOT. According to research Mardiastuti (2002) observed microscopically on alloxan-induced liver $125 \mathrm{mg} / \mathrm{kg}$ showed the presence of liver damage in the form of degeneration to necrose. BCSO at dose of $68 \mathrm{mg} / \mathrm{kg}$ showed a significant difference with the negative control $(\mathrm{p}<0.05)$. $\mathrm{BCSO}$ at a dose of $68 \mathrm{mg} / \mathrm{kg}$ have been able to prevent the increase in SGOT levels rats but not yet reached normal. Another study conducted by Juwita (2011) [14] proved that the administration of BCSO can lower elevated levels of SGPT and SGOT in rats induced by ethanol. Thymoquinone, the main active ingredient of Nigella sativa, has been reported to prevent liver damage in rats through antioxidative and anti-inflammatory mechanisms [15],[16]. Thymoquinone have antioxidant activity through the donation of electrons to free radicals [17],[18]. BCSO group of $68 \mathrm{mg} / \mathrm{kg}$ when compared with positive group that vitamin $\mathrm{C}$ had a significant difference, in which simvastatin group had higher levels closer to normal.

\subsection{Activity SGPT}

The result of SGPT are presented in Table 2. The results showed that administration at equivalent doses BCSO 6.8 and $68 \mathrm{mg} / \mathrm{kg}$ thymoquinone for 7 days did not affect the activity of SGPT. SGPT before induced by alloxan in rats given $\mathrm{BCSO}$ and vitamin $\mathrm{C}$ are not different from the normal group $(\mathrm{p}>0.05)$. The treatment given to the test animals did not affect the levels of SGOT and does not change the normal conditions but DMSO administration increases SGPT levels $(\mathrm{p}<0.05)$.

Tabel 2. Level of SGPT liver rats pre- and post-induced by alloxan and treated by BCSO or vitamin C

\begin{tabular}{ccc}
\hline \multirow{2}{*}{ Groups } & \multicolumn{2}{c}{ SGPT level } \\
\cline { 2 - 3 } & Pre (mean \pm SD) U/I & Post(mean \pm SD) U/I \\
\hline Normal & $18.73 \pm 0.638$ & $19.28 \pm 0.542^{\mathrm{a}}$ \\
Negative control (alloxan) & $18.15 \pm 0.268$ & $27.31 \pm 0.612^{*}$ \\
BCSO 6.8 & $18.44 \pm 0.396$ & $26,78 \pm 0.00^{*}$ ** $^{*}$ \\
BCSO 68 & $18.98 \pm 0.554$ & $24.97 \pm 0.473^{* \mathrm{a}}$ \\
Vitamin C & $17.96 \pm 0.592$ & $23.01 \pm 0.554^{* \mathrm{a}}$ \\
DMSO & $23.28 \pm 2.288^{*}$ & \\
\hline
\end{tabular}

Ext: $*=p<0.05$ (significant difference to normal group); $* *=p>0.05$ (not significant difference to alloxan group); ${ }^{\mathrm{a}}=\mathrm{p}<0.05$ (significant difference to alloxan group 
After induction of alloxan day 9 SGPT levels were normal group has significant difference compared to other treatment SGPT levels. SGPT levels of negative group compared with the normal group had significant differences. Giving alloxan affect SGPT levels are characterized by increased levels of SGPT mice was higher than normal control group [19]. According to research Mardiastuti (2002) [19],[20] observed microscopically on alloxan-induced liver $125 \mathrm{mg} / \mathrm{kg}$ showed the presence of liver damage in the form of degeneration to nekrose. BCSO group SGPT levels $6.8 \mathrm{mg} / \mathrm{kg}$ when compared with the negative group had no significant difference, indicating that the BCSO dose of $6.8 \mathrm{mg} / \mathrm{kg}$ have not been able to prevent the increase in SGPT levels alloxan-induced mice $(\mathrm{p}>0.05)$. BCSO equivalent dose of $68 \mathrm{mg} / \mathrm{kg}$ thymoquinone SGPT levels lower than negative group $(\mathrm{p}<0.05)$, indicating that BCSO equivalent dose of 68 $\mathrm{mg} / \mathrm{kg}$ thymoquinone can prevent and reduce levels of SGPT SD rats induced by alloxan. These results are supported by research conducted by Juwita [11],[21] that the provision of black cumin oil may lower elevated levels of SGPT and SGOT on ethanol-induced rats.

\section{3. p53 Expression}

The result of p53 expressions are presented in Table 3. Alloxan administration decreased p53 expression ( $\mathrm{p}>0.05)$. The results showed that administration at equivalent doses BCSO 6.8 and $68 \mathrm{mg} / \mathrm{kg}$ thymoquinone for 7 days increased of $\mathrm{p} 53$ expression $(\mathrm{p}<0.05)$.

Tabel 3. Percentage of mean p53 expression each group in rats induced by alloxan treated by BCSO or vitamin C

\begin{tabular}{cc}
\hline Groups & $\%$ mean p53 expression \\
\hline Normal & $11.12 \pm 0.37$ \\
Negative control (alloxan) & $19.24 \pm 4.47^{*}$ \\
BCSO 6.8 & $30.31 \pm 1.59^{* \mathrm{a}}$ \\
BCSO 68 & $40.43 \pm 1.74^{*^{\mathrm{a}}}$ \\
Vitamin C & $29.67 \pm 0.47^{\mathrm{a}}$ \\
DMSO & $12.02 \pm 1.01^{\mathrm{a}}$ \\
\hline
\end{tabular}

Ext: $*=p<0.05$ compare to normal group; ${ }^{a}=p<0.05$ compare to negative

(alloxan) control group

Table 3 shows that the BCSO have increased the expression of p53 activity when compared with the control group alloxan as sick. Expression of p53 in a dose of 68 BCSO group is the largest compared to the other groups in the amount of $40.43 \pm 1.74$. In the healthy control group contained p53 expression because apoptosis is one way to keep a balance (homeostasis) in the body. Normal cells have low levels of p53 protein because they have a short life, and have a latent form. Level and p53 activity increases cellular damage such as responding to DNA damage by exposure alloxan. Generally, the activity of p53 has a pivotal role in the cell cycle or programmed death (apoptosis) [22]. P53 protein was used to detect DNA damage, DNA repair help through the termination of the G1 phase of the cell cycle and DNA repair genes trigger. Damaged cells and DNA can not be repaired, then directed by p53 to undergo apoptosis. In normal cell growth, survival time is very short p53 in minutes, whereas if there is damage to DNA can live a longer time, which in a matter of hours. With the increased expression of p53 means it will directly drive the process of apoptosis. When the injured cells, p53 in the nucleus of cells triggered a temporary halt to the border G1 / S by inducing CDK inhibitors (cyclin D kinase) and DNA repair system in advance to eliminate the injury before the cell enters the $\mathrm{S}$ phase in the absence of injured DNA [22],[23].

Timoquinone is black cumin seed bioactive compounds that have antioxidant and immunomodulatory effects that can optimize the immune response against foreign substances or antigens [7],[8],[24]. Wirries et al. (2010) [25] stated that Thymoquinone, the main compound of black seed oil can induce pro-apoptotic signaling pathways. Treatment with cytostatic effect thymoquinone caused, mediated by up-regulation of p21 and down-regulation of cyclin E, which is associated with the arrest of S / G2 of the cell cycle. These findings indicate that Timoquinone can inhibit cell proliferation dependent on p53 status by activating the cell cycle inhibitor $\mathrm{p} 21$. Thymoquinone also can cause non-specific cytotoxic reactions, for example, due to the formation of oxidative stress.

\section{CONCLUSION}

a) BCSO at equivalent dose of $68 \mathrm{mg} / \mathrm{kg}$ thymoquinone have hepatoprotector effect by lowering SGPT and SGOT levels in rats induced by alloxan.

b) BCSO may increase the expression of p53 in the liver of rats induced by alloxan. 
c) $\mathrm{BCSO}$ at equivalent dose of $6.8 \mathrm{mg} / \mathrm{kgWB}$ thymoquinone can increase p53 expression equivalent to the administration of vitamin $\mathrm{C}$ in the liver in rats induced by alloxan.

\section{ACKNOWLEDGEMENTS}

Directorate General of Higher Education (DIKTI), Republic of Indonesia who helped finances this study.

\section{REFERENCES}

[1] Price, S. A., Wilson, L. M., "Disease Procest clinical Concept Pathophysiology Disease Processt", diterjemahkan oleh Brahm, U., Huriawati, H., Pita, W., Dewi, A.M., EGC, Jakarta, vol/issue: 6(6), pp. 475-479, 2005.

[2] Crowin, E. J., "Handbook of Pathophysiology", $2^{\text {nd }}$ ed, Lippincott, New York, pp. 573, 2000.

[3] Sizer, F. S. E., Whitney, "Nutrition Concept and Controversies", Belmont, USA, Thompson Wadsworth, pp. 118-9; 121:157, 2007.

[4] Armstrong, D., Gadoth, N., Gobel, H. H., "Oxidative Stress in Applied Basic Research and Clinical Practice: Oxidative Stress and Free Radical Damage in Neurology”, HUMANA Pres, Springer, New York, 2011.

[5] Nickavar B., Mojab, F., Javidnia, K., Amoli, M. A., "Chemical composition of the fixed and volatile oils of Nigella sativa L. from Iran", J. Naturforsch, vol/issue: 58(9-10), pp. 629-31, 2003.

[6] El Sayed I., Fukushima S., "Chemopreventive potential of volatile oil from black cumin (Nigella sativa L) seeds against rat colon carcinogenesis", J. of Nutrit and Cancer, vol/issue: 45(2), pp. 195-202, 2003.

[7] Farrah, K. M., "Mechanisms of the hypoglycaemic and immunopotentiating effects of Nigella sativa L. oil in streptozotocin-induced diabetic hamsters", 2001.

[8] Salem, M. L., "Immunomodulatory and therapeutic properties of the Nigella sativa L. Seed", International Imunopharmacol, vol. 5, pp. 1749-1770, 2005.

[9] Mursito, "Traditional herb for malaria", Penebar Swadaya, Jakarta, 2002.

[10] Purnama, A., "The effect of Echinacea purpurea on the production of IFN gamma and tumor cell apoptosis index of mice with breast cancer who are experiencing stress", Dissertation, UniversitasDiponegoro, Semarang, 2008.

[11] Giknis, M.L.A., Clifford, C.B., "Clinical laboratory parameters for Crl:WI (Han) Sprague Dawley Rat", Charles River Laborato, 2008.

[12] Himawan, R., "Effect of Green Tea Leaf Extract (Camellia sinensis) against SGPT levels Rats (Rattus novergicus) Induced by Isoniazid”, Skripsi, Universitas Sebelas Maret, Surakarta, 2008.

[13] Walter H. Hsu, "Handbook of Veterinary Pharmacology", $5^{\text {th }}$ edition, lowa State University, Lowa, 2008.

[14] Juwita, R., "Effect of Black Cumin Oil (Nigella sativa) for ALT and AST levels in the White Rat (Rattus novergicus) Model Hepatotoxicity (Ethanol)", Skripsi, Universitas Jendral Soedirman, Purwokerto, 2011.

[15] El aziz, M. A., Hassan, H. A., Mohammad, M. H., Meki, A. R., "The biochemical and morphological alterations following administration of melatonin, retinoic acid and Nigella sativa in mammary carcinoma: an animal model", int. J. ExpPathol, vol/issue: 86(6), pp. 383-96, 2005.

[16] Randhawa, M. A., Al-Ghamdi, M. S., "A Review of the pharmacotherapeutic effects of Nigella sativa", Pakistan J.Med. Res., vol/issue: 41(2), pp. $21-31,2002$.

[17] Salem, M. L., "Immunomodulatory and therapeutic properties of the Nigella sativa L. seed", International Immunopharmacology, vol. 5, pp. 1749 - 1770, 2005.

[18] Shahzad, M., Yang, X., Asim, M. B. R., Sun, Q., Han, Y., Zhang, F., Cao, Y., Lu, S., "Black seed oil ameliorates allergic airway inflammation by inhibiting T-cell proliferation in rats", Pulmonary Pharmacology \& therapeutics, vol. 22 , pp. $37-43,2009$.

[19] Mardiastuti, E., "Gambaran Histopatologi Organ Hati dan Ginjal Tikus Diabetes Mellitus yang Diberi Infus Batang Brotowali (Tinosporatuberculata) sebagai Bahan Antidiabetik, Skripsi, Institut Pertanian Bogor, Bogor, 2002.

[20] Lenzen, S., "The Mechanisms of alloxan and streptozotocin-induced diabetes", Diabetologia, vol. 51, pp. 216-226, 2007.

[21] Szkudelski, T., "The Mechanism OfAlloxanAndStreptozotocin Action In $\beta$ Cells of The Rat Pancreas", Physiology Research, vol. 50, pp. 536-54, 2001.

[22] Syaifudin, M., “Gen Penekan Tumor p53, Kanker dan Radiasi Pengion”, Buletin Alara, vol/issue: 8(3), pp. 119$128,2007$.

[23] Siu, W. Y., Yam, C. H., Poon, R. Y. C., "G1 versus G2 Cell Cycle After Adriamycin-induced Damage in Mouse Swiss3T3 Cells", Left, vol. 461, pp. 299-305, 1999.

[24] Akrom, Khoiri N., Suhana, Y., Mustofa, "The effect of the ethanol extract of black cumin seeds against phagocytic activity and ROI secretion of macrophages of male mice strain Balb C in vitro", Seminar Nasional Tanaman Obat Dan Obat Tradisional, Balai besar penelitian dan pengembangan tanaman obat badan litbang kesehatan, Departemen kesehatan RI, Solo, 10-11 July 2007.

[25] Wirries, A., Breyer, S., Quint, K., Schobert, R., "Thymoquinonehydrazone derivatives cause cell cycle arrest in p53 competent colorectal cancer cells", experimental and therapeutic medicine, vol. 1, pp. 369-375, 2010. 